\title{
Case report: Efficacy of ponatinib in a case of chronic myeloid leukemia with a complicated clonal evolution including a myelodysplastic syndrome
}

William McCarvill, Harold J Olney, Xiaoduan Weng, Boli Fan and Denis Soulières*

*Correspondence: denis.soulieres@umontreal.ca

CrossMark

$\leftarrow$ Click for updates

Department of Medicine, Service of Hemato-Oncology, Centre Hospitalier de I'Université de Montréal, Montréal, Québec, Canada.

\begin{abstract}
Chronic myeloid leukemia (CML) is characterised by the presence of the Philadelphia chromosome (Ph), which results in the production of the constitutively active tyrosine kinase BCR-ABL1, with tyrosine kinase inhibitors (TKI) targeted against this protein now being the mainstay of therapy. Clonal evolution in Ph-positive cells is rather uncommon in the chronic phase of CML (CP-CML) but is associated with disease progression, and although chromosomal abnormalities in Ph-negative cells have been described during imatinib therapy and more recently with newer TKIs, albeit rarely, clinical consequences remain unclear. Some of these patients do however evolve to a myelodysplastic syndrome (MDS) or an acute myeloid leukemia (AML), with loss of chromosome 7 seeming to confer the highest risk.

The case is that of a patient with CP-CML diagnosed in 2008 who initially experienced secondary resistance to imatinib, with the $\mathrm{G} 25 \mathrm{OE}$ and $\mathrm{E} 459 \mathrm{~K}$ point mutations in the BCR-ABL1 kinase domain (KD) being detected. Secondary resistance to dasatinib later developed, and this time the F317L BCRABL1 KD mutation was detected. Furthermore, a MDS with features of poor prognosis including loss of chromosome 7 in Ph-negative cells was diagnosed in 2012 while she was demonstrating a deep molecular response of her CML on nilotinib therapy. Azacitidine was added and resulted in a response of the MDS with a transfusion independency. The -7 clone was never again detected, but a gain of chromosome $8(+8)$ was found on subsequent cytogenetic studies, as well as a sub-clone of Ph-positive cells harboring a $t(5 ; 20)$ (q32;q13) translocation. Due to loss of molecular and cytogenetic responses of her CML on nilotinib, the patient was switched to ponatinib and azacitidine was stopped. This resulted in a sustained major molecular response of her CML at 24 months, with no signs of recurrence of the MDS. Interestingly, the +8 clone has persisted on two cytogenetic studies performed after initiating ponatinib.

This report raises important issues regarding the natural history of CML and to the significance of seemingly independent Ph-negative clones identified during TKI therapy, as well as suggesting the efficacy of ponatinib in the presence of complicated clonal and mutational evolution of the Ph-positive cells as well as a MDS.
\end{abstract}

Keywords: Chronic myeloid leukemia, ponatinib, loss of chromosome 7, gain of chromosome 8, secondary myelodysplastic syndrome, clonal evolution, CML, chromosomal cytogenetic abnormalities, monosomy 7 , trisomy 8

\section{Introduction}

Chronic myeloid leukemia (CML) is a clonal myeloproliferative neoplasm characterized by dysregulated clonal proliferation of mainly myeloid but also erythroid cells and platelets. The
Philadelphia chromosome $(\mathrm{Ph})$, resulting from the $\mathrm{t}(9 ; 22)$ (q34;q11) reciprocal translocation, is characteristic of the disease and results in the production of the dysregulated tyrosine kinase BCR-ABL1, at the heart of the pathogenesis of CML [1]. 
McCarvill et al. Hematology and Leukemia 2018,

http://www.hoajonline.com/journals/pdf/2052-434X-6-3.pdf

doi: 10.7243/2052-434X-6-3

CML historically progressed from a rather indolent chronic phase (CP-CML) to an accelerated phase where the disease is harder to control and generally culminating in an acute leukemia or blast crisis (BC-CML), although this is rare since the introduction of tyrosine kinase inhibitors (TKI) directed against BCR-ABL1.

TKIs are now the mainstay of therapy for $\mathrm{CP}-\mathrm{CML}$, with imatinib, dasatinib and nilotinib representing first-line treatment options for such patients [2]. Different mechanisms can contribute to TKI resistance, with point mutations in the $B C R$ $A B L 1$ kinase domain (KD) being a well described mechanism of acquired resistance to imatinib $[3,4]$. Ponatinib is a new TKI that has shown activity against $C P-C M L$ resistant to first and second-generation TKIs due to $B C R-A B L 1 \mathrm{KD}$ mutations and is the only currently available TKI active against the T315I mutation [5-7].

Monitoring response to TKI therapy has historically been done using various methods, with quantitative real time polymerase chain reaction (qRT-PCR) measurement of BCR-ABL1 transcript level on the international scale (IS) now being used to monitor molecular response to treatment $[2,8]$. Nonetheless, fluorescence in situ hybridization (FISH) and conventional cytogenetic studies on bone marrow specimens are still recommended at diagnosis, with the latter remaining of great value in cases of treatment failure to identify possible evolution of the CML clone or clonal chromosomal abnormalities (CCAs) in Ph-negative cells $[2,9]$. BCR-ABL1 mutational analyses are also recommended in cases of treatment failure [2]. Recurrent molecular mutations involving other genes than $B C R-A B L 1$, such as $A S X L 1, R U N X 1$, and TET2, amongst others, seem to be common in BC-CML patients but have also been identified in a small proportion of $\mathrm{CP}-\mathrm{CML}$ patients with unclear prognostic implications, and data is currently lacking to recommend searching for such mutations $[10,11]$.

CCAs in Ph-positive cells is identified in $5 \%$ of CP-CML patients but is present in $50-80 \%$ of BC-CML cases [12]. They are a feature defining treatment failure or an accelerated phase of CML $[2,13]$. They are thought to reflect the genetic instability of the CML progenitors, conferred at least partly by the BCR-ABL1 protein [14-16]. Clonal evolution of Ph-positive cells can therefore manifest itself as CCAs in addition to the $\mathrm{Ph}$ chromosome, point mutations in BCR-ABL1 (usually in the $\mathrm{KD}$ ) or mutations in other genes.

CCAs in Ph-negative cells arising during treatment for CML are rare and were initially described in patients exposed to chemotherapy and interferon-a but are increasingly reported in patients treated with imatinib, and more recently dasatinib and nilotinib, with cases now reported in patients treatment naive before the use of TKIs [17-21]. These anomalies have unclear clinical implications, with only a minority of patients eventually developing a secondary hematological neoplasm such as a myelodysplastic syndrome (MDS) and/or acute myeloid leukemia (AML) [18,21-23]. Loss of chromosome 7 (-7) seems to confer the highest risk for secondary MDS/AML, based on case series and anecdotal reviews [23]. In a literature review by Groves and al in 2011, 16 of 53 patients with TKI-treated CML in whom -7 or del(7q) was identified developed a MDS/ AML, with -7 present in all cases [19]. The latest European Leukemia Net recommendations on the management of CML consider -7 or del(7q) in Ph-negative cells as a warning sign requiring more frequent monitoring [2].

Myelodysplastic syndromes form a heterogeneous group of clonal malignant neoplasms that have a variable risk of progression to AML and are characterized by dysplastic and ineffective hematopoiesis. This results in peripheral blood cytopenias with expected clinical consequences and dysplastic changes on bone marrow examination [24]. They can arise following cytotoxic chemotherapy given for another neoplasm and, as mentioned, have been described in a few cases of patients receiving TKI therapy for CML. Progression of CML in such patients must however be excluded. MDS treatment varies according to risk stratification on the revised International Prognostic Scoring System (R-IPSS) risk score, which incorporates the karyotype and patient characteristics [25]. Options include supporting care such as transfusions and growth factors, active treatment with hypomethylating agents such as azacitidine or decitabine to stabilize and modify the course of the disease, with allogeneic hematopoietic stem cell transplantation (alloSCT) being a potentially curative option available to a minority of patients [26].

\section{Case presentation}

The patient presented with asthenia and abdominal pain in September 2008 at 58 years old. A complete blood count revealed leucocytosis at $669 \times 10^{9} / \mathrm{L}$ with $3 \%$ myeloblasts on immunophenotyping, anemia at $84 \mathrm{~g} / \mathrm{L}$ and a platelet count of $355 \times 10^{\%} / \mathrm{L}$. She was not known for any other prior medical condition. The Philadelphia chromosome as well as a typical e14a2 BCR-ABL1 transcript subtype were identified and she was therefore diagnosed with CP-CML. Unfortunately, the original bone marrow aspirate was inadequate for cytogenetic studies. The JAK2 V617F mutation was not identified. Table 1 summarizes the findings of all the cytogenetic studies that were done since diagnosis, along with marrow characteristics and $B C R-A B L 1 \mathrm{KD}$ mutations detected. Figure 1 details the molecular response over time along with the treatment history.

The patient was immediately started on imatinib and hydroxyurea for the important leucocytosis. A BCR-ABL1 transcript level of $0.135 \%$ on the IS, was obtained in April 2009 but, in July 2009 , there was a loss of the molecular response confirmed on subsequent specimens with a BCR-ABL1 transcript level of $18.2 \%$ IS in December 2009, as well as an increasing thrombocythemia. She was therefore put on dasatinib as second line treatment in February 2010. A search for mutations in the $B C R-A B L 1 \mathrm{KD}$ was performed at another center at the end of 2009 with two mutations identified using the amplification-refractory mutation system, specifically a G250E and an E459K. While on dasatinib, the patient only achieved 
McCarvill et al. Hematology and Leukemia 2018,

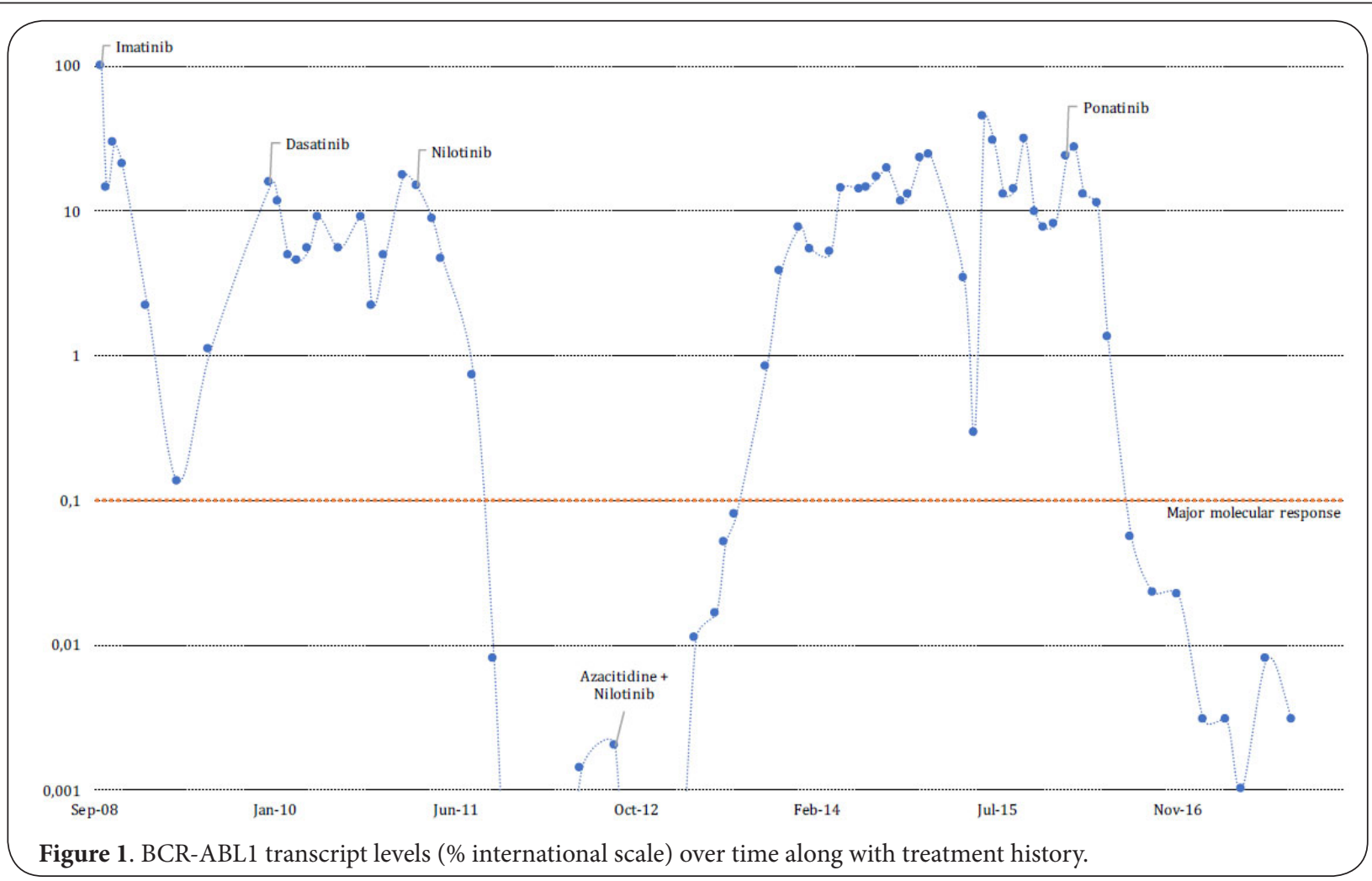

Table 1. Results of G-banding cytogenetic analyses performed on bone marrow cells in metaphase along with BCR-ABL1 transcript levels illustrating CML disease status, treatment received at the time with bone marrow characteristics and blood count results.

\begin{tabular}{|c|c|c|c|c|c|c|c|}
\hline Date & Karyotype* & $\begin{array}{l}\text { BCR-ABL1 transcript level } \\
\text { (\% International scale) }{ }^{\dagger}\end{array}$ & FISH ${ }^{\ddagger}$ & Marrow characteristics & Blood count ${ }^{t}$ & Treatment & $\begin{array}{l}\text { BCR-ABL1 kinase } \\
\text { domain mutation } 5\end{array}$ \\
\hline $22 / 09 / 2008$ & $\mathrm{~N} / \mathrm{A}$ & $100 \%$ & $77.8 \%$ & $\begin{array}{l}2 \% \text { blasts } \\
\text { Very important cellularity with } \\
\text { an important granulocytic } \\
\text { component but no dysplasia }\end{array}$ & $\begin{array}{l}\text { WBC } 669.2 \times 10^{9} / \mathrm{L} \\
\text { ANC } 107.2 \times 10^{9} / \mathrm{L} \\
\text { Hb } 84 \mathrm{~g} / \mathrm{L} \\
\text { PLT } 355 \times 10^{9} / \mathrm{L}\end{array}$ & $\begin{array}{l}\text { Imatinib }+ \\
\text { Hydroxyurea }\end{array}$ & N/A \\
\hline $23 / 11 / 2009$ & $\begin{array}{l}46, \mathrm{XX}, \mathrm{t}(9 ; 22)(\mathrm{q} 34 ; \mathrm{q} 11.2)[15] \\
46, \mathrm{XX}[3] \\
46, \mathrm{XX}, \operatorname{del}(6)(\mathrm{q} 21 \mathrm{q} 27), \mathrm{t}(9 ; 22)[3]\end{array}$ & $5.302 \%$ & $0.2 \%$ & N/A & $\begin{array}{l}\text { WBC } 8.9 \times 10^{9} / \mathrm{L} \\
\text { ANC } 5.2 \times 10^{9} / \mathrm{L} \\
\text { Hb } 112 \mathrm{~g} / \mathrm{L} \\
\text { PLT } 1497 \times 10^{9} / \mathrm{L}\end{array}$ & Dasatinib & $\begin{array}{l}\mathrm{G} 250 \mathrm{E}+\mathrm{E} 459 \mathrm{~K} \\
\mathrm{G} 250 \mathrm{E}+\mathrm{E} 459 \mathrm{~K}+ \\
\mathrm{F} 317 \mathrm{~L}\end{array}$ \\
\hline $14 / 02 / 2011$ & N/A & $14.573 \%$ & $51.2 \%$ & $\begin{array}{l}4 \% \text { blasts (no } \\
\text { immunophenotyping) } \\
\text { No dysplasia }\end{array}$ & $\begin{array}{l}\text { WBC } 6.8 \times 10^{9} / \mathrm{L} \\
\text { ANC } 4.2 \times 10^{9} / \mathrm{L} \\
\text { Hb } 114 \mathrm{~g} / \mathrm{L} \\
\text { PLT } 1218 \times 10^{9} / \mathrm{L}\end{array}$ & $\begin{array}{l}\text { Dasatinib } \rightarrow \\
\text { Nilotinib }\end{array}$ & F317L \\
\hline $05 / 06 / 2012$ & $\begin{array}{l}46, \mathrm{XX},-7,+22[15] \\
46, \mathrm{XX}[5]\end{array}$ & $0.0014 \%$ & $0.0 \%$ & $\begin{array}{l}0 \% \text { blasts ( } 8 \% \text { on } \\
\text { immunophenotyping) } \\
\text { No dysplasia }\end{array}$ & $\begin{array}{l}\text { WBC } 2.8 \times 10^{9} / \mathrm{L} \\
\text { ANC } 1.3 \times 10^{9} / \mathrm{L} \\
\text { Hb } 110 \mathrm{~g} / \mathrm{L} \\
\text { PLT } 253 \times 10^{9} / \mathrm{L}\end{array}$ & Nilotinib & N/A \\
\hline $02 / 04 / 2013$ & N/A & $\begin{array}{l}\text { Negative (no BCR-ABL1 } \\
\text { transcript found) }\end{array}$ & $\mathrm{N} / \mathrm{A}$ & $\begin{array}{l}0 \% \text { blasts ( } 16 \% \text { on } \\
\text { immunophenotyping) } \\
\text { Tri-lineage dysplasia }\end{array}$ & $\begin{array}{l}\text { WBC } \times 10^{9} / \mathrm{L} \\
\text { ANC } 0.2 \times 10^{9} / \mathrm{L} \\
\text { Hb } 114 \mathrm{~g} / \mathrm{L} \\
\text { PLT } 158 \times 10^{9} / \mathrm{L}\end{array}$ & Nilotinib & N/A \\
\hline $12 / 11 / 2013$ & $\begin{array}{l}46, \mathrm{XX}, \mathrm{t}(9 ; 22)(\mathrm{q} 34 ; \mathrm{q} 11.2)[2] \\
46, \mathrm{XX}, \mathrm{t}(9 ; 22)(\mathrm{q} 34 ; \mathrm{q} 11.2), \mathrm{t}(5 ; 20)(\mathrm{q} 32 ; \mathrm{q} 13)[10] \\
47, \mathrm{XX},+8[6] \\
46, \mathrm{XX}[2]\end{array}$ & $3.841 \%$ & $13.7 \%$ & $\begin{array}{l}1 \% \text { blasts ( } 3 \% \text { on } \\
\text { immunophenotyping) } \\
\text { Tri-lineage dysplasia }\end{array}$ & $\begin{array}{l}\text { WBC } 1.0 \times 10^{9} / \mathrm{L} \\
\text { ANC } 0.3 \times 10^{9} / \mathrm{L} \\
\text { Hb } 105 \mathrm{~g} / \mathrm{L} \\
\text { PLT } 177 \times 10^{9} / \mathrm{L}\end{array}$ & $\begin{array}{l}\text { Nilotinib + } \\
\text { Azacitidine }\end{array}$ & N/A \\
\hline $13 / 04 / 2015$ & $\begin{array}{l}46, \mathrm{XX}, \mathrm{t}(9 ; 22)(\mathrm{q} 34 ; \mathrm{q} 11.2)[5] \\
46, \mathrm{XX}, \mathrm{t}(9 ; 22)(\mathrm{q} 34 ; \mathrm{q} 11.2), \mathrm{t}(5 ; 20)(\mathrm{q} 32 ; \mathrm{q} 13)[15]\end{array}$ & $3.393 \%$ & $74.6 \%$ & $\begin{array}{l}5 \% \text { blasts ( } 7 \% \text { on } \\
\text { immunophenotyping) } \\
\text { Tri-lineage dysplasia }\end{array}$ & $\begin{array}{l}\text { WBC } 11.9 \times 10^{9} / \mathrm{L} \\
\text { ANC } 6.55 \times 10^{9} / \mathrm{L} \\
\text { Hb } 116 \mathrm{~g} / \mathrm{L} \\
\text { PLT } 747 \times 10^{9} / \mathrm{L}\end{array}$ & $\begin{array}{l}\text { Nilotinib+ } \\
\text { Azacitidine }\end{array}$ & F317L \\
\hline $10 / 05 / 2016$ & $\begin{array}{l}47, \mathrm{XX},+8[16] \\
48, \mathrm{XX},+8,+8[1] \\
48, \mathrm{XX},+8,+8,+\operatorname{mar}[1] \\
46, \mathrm{XX}[3]\end{array}$ & $1.336 \%$ & $2.0 \%$ & $\begin{array}{l}5 \% \text { blasts } \\
\text { No dysplasia }\end{array}$ & $\begin{array}{l}\text { WBC } 4.1 \times 10^{9} / \mathrm{L} \\
\text { ANC } 2.61 \times 10^{9} / \mathrm{L} \\
\mathrm{Hb} 119 \mathrm{~g} / \mathrm{L} \\
\text { PLT } 76 \times 10^{9} / \mathrm{L}\end{array}$ & Ponatinib & N/A \\
\hline $24 / 10 / 2016$ & $\begin{array}{l}47, \mathrm{XX},+8[10] \\
46, \mathrm{XX}[10]\end{array}$ & $0.022 \%$ & $0.0 \%$ & $\begin{array}{l}1 \% \text { blasts } \\
\text { No dysplasia }\end{array}$ & $\begin{array}{l}\text { WBC } 5.9 \times 10^{9} / \mathrm{L} \\
\text { ANC } 3.8 \times 10^{9} / \mathrm{L} \\
\mathrm{Hb} 133 \mathrm{~g} / \mathrm{L} \\
\text { PLT } 154 \times 10^{9} / \mathrm{L}\end{array}$ & Ponatinib & N/A \\
\hline
\end{tabular}

* The number of metaphases in which the clones were identified are indicated in the brackets

$\dagger$ BCR-ABL1 transcript levels and blood count values obtained closest to the bone marrow biopsy are listed here since blood tests were not always obtained on the day of the biopsy. All results are within one month of the date the aspiration/biopsy was done

\$ Fluorescence in situ hybridization

$\$$ Mutational analyses on the specimens at diagnosis, in 2009 and 2011 done using the amplification-refractory mutation system, with the analysis in 2015 done using Sanger sequencing. 
McCarvill et al. Hematology and Leukemia 2018,

http://www.hoajonline.com/journals/pdf/2052-434X-6-3.pdf

doi: 10.7243/2052-434X-6-3

a partial hematological response with persistent thrombocytosis, and the lowest BCR-ABL1 transcript level was at $2.18 \%$. The F317L BCR-ABL1 KD mutation was detected in another center early 2011. A mutational analysis was performed at our center at the same time but on a specimen from December 2009 and the three mutations G250E, E459K and F317L were detected. This mitigated response as well as the emergence of the F317L mutation, which is associated with dasatinib resistance [2,27], prompted a switch to nilotinib in February 2011. No family donor for a potential alloSCT was identified. A complete cytogenetic response was achieved at 4 months and a deep molecular response at 10 months without any $B C R-A B L 1$ transcripts detected by qRT-PCR, with a detection limit of at least 1 in $10^{4.5}$ cell in our laboratory.

MDS was suspected in 2012 after the blood count revealed progressive cytopenias. Cytogenetic studies on a bone marrow specimen revealed a clonal population of $\mathrm{Ph}$-negative cells in 15 metaphases harboring -7 as well as gain of chromosome $22(+22)$, while the patient had a deep molecular response (defined as a BCR-ABL1 transcript level less than $0.0032 \%$ ) of her CML with a BCR-ABL1 transcript level of $0.0014 \%$. The bone marrow did not reveal any dysplasia but immunophenotyping studies did identify $8 \%$ myeloblasts. An MDS was diagnosed and azacitidine was started soon afterwards based on her high R-IPSS score. A bone marrow examination revealed tri-lineage dysplasia in April 2013, with $16 \%$ blasts on immunophenotyping. The deep molecular response to nilotinib was sustained until June 2013 when the BCR-ABL1 transcript level started to rise, with a subsequent confirmed loss of the major molecular response on a subsequent specimen in November 2013. Tri-lineage dysplasia was present in the bone marrow at this time, with cytogenetic studies revealing the presence of Ph-positive cells with $\mathrm{t}(5 ; 20)(\mathrm{q} 32 ; \mathrm{q} 13)$ in 10 metaphases and $\mathrm{Ph}$-negative cells with +8 in 6 metaphases. The clones harboring -7 and +22 were not identified. The blood count later revealed an important thrombocytosis in 2014. On control bone marrow cytogenetic studies in April 2015 , the Ph chromosome was present in all metaphases, with $t(5 ; 20)(q 32 ; q 13)$ present in 15 metaphases. Significant tri-lineage dysplasia was present in the bone marrow. No new $B C R-A B L 1$ KD mutation was detected.

Nilotinib and azacitidine were stopped in January 2016 and the patient was switched to ponatinib $30 \mathrm{mg}$ daily. A complete hematological response was obtained at three weeks with a major molecular response (MMR) obtained at 6 months, followed by a deep molecular response at one year. No evidence of myelodysplasia was found on two control medullary biopsies in 2016, although cells with +8 have persisted on cytogenetic studies. Ponatinib dosage was reduced to $15 \mathrm{mg}$ alternating with $30 \mathrm{mg}$ in January 2017 due to hypertension and sinus tachycardia, which were considered as treatment related side-effects. At two years, the molecular response is sustained with no recurrence of the MDS, and ponatinib is currently well tolerated at the adjusted doses.

\section{Discussion}

This is an interesting case because this patient, over the course of her disease, developed secondary resistance to the three TKls approved as first-line treatment for CML, as well as developing a poor prognosis MDS according to R-IPSS. This led us to treat her with the hypomethylating agent azacitidine concurrently with nilotinib, before ultimately switching to ponatinib alone two years ago, resulting in a sustained MMR of her CML without recurrence of a MDS phenotype. Different mutations and cytogenetic abnormalities in the Ph-positive clonal population as well as CCAs in Ph-negative cells have been identified since diagnosis, with some having had important clinical consequences and therapeutic implications.

Since the introduction of imatinib, the first TKI targeting the BCR-ABL1 tyrosine kinase, four other TKls have been approved in North America, with ponatinib being the latest and first third-generation TKI. These treatment options have revolutionized the treatment of CML with life expectancy now approaching that of the general population [28]. TKIs induce a rapid and sustained molecular response in most patients with CP-CML, with a MMR associated with a durable complete cytogenetic response [29]. However, a minority of patients, especially those presenting a high tumor burden, eventually develop resistance, with some rarely developing resistance to more than one TKI [30]. This patient harboring three $B C R$ $A B L 1$ KD mutations represents such a case as she eventually developed secondary resistance to imatinib, dasatinib and nilotinib. It is important to note that she achieved a deep molecular response to nilotinib which was subsequently lost, which is uncommon. Choice of therapy can be challenging after multiple TKI failure, with ponatinib, a newly available third-generation TKI as well as bosutinib, a second-generation TKI, remaining available options that could be tried before considering alloSCT in these patients [2,31]. AlloSCT remains a potential curative treatment for CML but is rarely performed nowadays due to the efficacy of TKIs and toxicity concerns in elderly patients [2]. Another issue specific to this case is that no reports are available that evaluate the outcome of alloSCT in cases of a MDS present concurrently with CML. Still, it was considered at the time, but no family donor was identified. An unrelated donor could have been an option, but age was initially seen as a limitation, and after discussion with the patient it was decided to try ponatinib.

Three point mutations in the $B C R-A B L 1 \mathrm{KD}$ were identified over the course of her disease which probably explains the acquired and sequential resistance to imatinib and dasatinib. G250E, F317L and E459K have been implicated in imatinib resistance $[4,7,32]$. The patient did however exhibit a significant molecular response with imatinib, suggesting that these mutations were either acquired during therapy or represented undetectable clones at diagnosis that were then selectively advantaged during TKI therapy. G250E and E459K were not detected on the last two analyses, confirming the efficacy of dasatinib in treating these clones and suggesting that they 
probably were polyclonal and not compound mutations. Treatment failure to dasatinib confirms reports suggesting resistance of the F317L mutation to this TKI $[2,27,33]$. This mutation has been described to be sensitive to nilotinib, suggesting another mechanism of resistance was responsible for nilotinib treatment failure [32]. Ponatinib has been shown to be active against all the $B C R-A B L 1 \mathrm{KD}$ mutations when present individually [7].

Pathogenesis of clonal evolution of Ph-positive clones has been studied, with BCR-ABL1 playing an important role in hindering DNA repair processes and possibly in promoting DNA damage [14-16]. This genetic instability plays a major role in the progression of CP-CML to more advanced stages of disease, with leukemic cells in BC-CML usually having accumulated many different mutations. In this patient, the first evolution of the Ph-positive cells identified was the development of $B C R-A B L 1 \mathrm{KD}$ mutations, with subsequent development of a Ph-positive subclonal population demonstrating $t(5 ; 20)(q 32 ; q 13)$. To our knowledge, this translocation has not been previously reported in CML or MDS, so its clinical significance is unclear. However, deletions and translocations involving $5 q 32$ as well as deletions in $20 q 13$ are associated with myeloproliferative neoplasms and MDS $[23,34-36]$. Most notably, $5 q 32$ is included in the deleted region in patients with the 5q- syndrome, a sub-type of MDS [34].

Recurrent CCAs in Ph-negative cells have been described in different reports, most often involving chromosomes 7, 8 and $\mathrm{Y}$, although they remain a rare occurrence, with an incidence varying between 3 and 17\% [23]. The origin of such clones is subject to controversy, with different possible mechanisms proposed over the years. One hypothesis is that a pathological clonal population may precede the acquisition of the $\mathrm{Ph}$ chromosome, which would imply a two-step pathogenesis to CML with the first event yet-to-be-identified. However, CCAs in Ph-negative cells are most often not present in $\mathrm{Ph}$ positive cells, as is the case in this report, which goes against this mechanism [18]. Initially, CCAs in Ph-negative cells were reported in patients treated with chemotherapy and interferon, suggesting that these agents might have been involved in the pathogenesis of these aberrations [17]. However, CCAs in Ph-negative cells have been described in patients treated with TKIs up-front, which prompted some to suggest that TKI toxicity could result in such aberrations $[20,37,38]$.

Another aspect which remains controversial is the prognostic significance of these CCAs in Ph-negative cells. Only a minority of patients harbouring such an aberration will develop a second hematological malignancy such as an MDS and/or AML. As mentioned, aberrations involving chromosome 7 seem to confer the greatest risk, but the majority of such patients still don't develop a MDS/AML [19]. Transient -7 appearing during TKI therapy has also been reported $[18,21,39]$. In this case presentation, -7 and +22 in the same clone was the first CCA identified in Ph-negative cells and coincided with the appearance of cytopenias in June 2012. Dysplasia was not observed on this bone marrow specimen, but it was present in April 2013 when no BCR-ABL1 transcripts were identified using qRT-PCR, indicating that a MDS was effectively present and that the manifestations did not simply result from progression of the CML. A question raised by these observations is whether the $\mathrm{Ph}$-negative clone harbouring -7 and +22 was responsible for the MDS or was simply a coincidental finding. Assuming it was responsible, another question remaining is why the myelodysplasia persisted after the disappearance of this clone. The +8 clone probably is not responsible for the MDS since it persisted after the correction of the cytopenias and the disappearance of the dysplasia in the bone marrow under ponatinib therapy. Trisomy 8 seems to represent the genetic instability of the bone marrow precursors in this patient, without necessarily representing any specific hematological disease, as has been observed in other reports [23].

The pathogenesis of MDS/AML developing during TKI therapy remains largely unclear, and it is difficult to say if they represent two manifestations of a common underlying hematopoietic disease or are two independent entities. As mentioned, only a minority of patients harboring CCAs in $\mathrm{Ph}$ negative clones will develop an MDS/AML, even in patients with $-7[18,19,23]$. In this report, the patient exhibited many different clonal populations over the course of her disease, suggesting the presence of an underlying susceptibility of her bone marrow progenitors to mutate, independent of their $B C R-A B L 1$ status. Perhaps the MDS in this case is most probably the result of the mutational burden and not just the result of a single anomaly. A search for mutations in genes other than $B C R-A B L 1$ has not been performed in this patient, as clinical implications of such findings remain unclear. However, a recently published case report described a patient with a CML and MDS with -7, well controlled with azacitidine and dasatinib but eventually relapsing, with de novo KRAS, ASXL1 and ETV6 gene mutations being the only new genetic anomalies identified at relapse [40]. Recent studies have also shown that such mutations are frequent in both $\mathrm{Ph}$-negative and positive clone populations [41]. In MDS, some of these recurrent mutations were associated with poor survival [42]. More research is necessary to clarify the significance of these mutations in such diseases but these recent publications suggest there might be a role for molecular genetic analysis in the management of refractory CML.

Ponatinib is a multi-target TKI active against native and mutated forms of $B C R-A B L 1$ [5]. It has also shown in vitro activity against FLT3, KIT, FGFR1 and PDGFRa [43]. When this TKI was started early 2016 in this patient, the CML had clearly relapsed with only $\mathrm{Ph}$-positive clones identified on chromosome banding analyses. Significant dysplasia was still present in the marrow. If we then assume that the MDS was still present at the start of ponatinib, it remains unclear why it disappeared without any other MDS-specific treatment and if ponatinib could have had an effect on the MDS clone. On the other hand, ponatinib did not eliminate the Ph-negative 
McCarvill et al. Hematology and Leukemia 2018,

http://www.hoajonline.com/journals/pdf/2052-434X-6-3.pdf

doi: $10.7243 / 2052-434 X-6-3$

clones harbouring +8 , suggesting it has little effect on this clonal population.

\section{Conclusion}

While most CP-CML patients have a sustained response to first-line TKIs, the reason why a minority of patients in CP-CML go on to develop genomic variations and a clonal evolution leading to a treatment-resistant disease, such as in this patient, remains unclear. This case raises important questions regarding the natural history of CML as well as on the clinical significance of Ph-negative clonal hematopoiesis in TKI-treated CML patients, especially in those developing a second hematologic malignancy. The origin of these Ph-negative clones and the possible role of TKIs in their pathogenesis, along with their possible relation to $\mathrm{Ph}$-positive clones is an area open for research. This report illustrates the efficacy and safety of a hypomethylating agent combined with a TKI to treat an MDS as well as the CML. Finally, this report specifically emphasizes the sustained efficacy of ponatinib in treating CML refractory to multiple TKIs, as previously reported, and possibly who present multiple genomic aberrations, as is the case here. The F317L BCR-ABL1 KD mutation was also observed to be sensitive to ponatinib, as has also been described. The possible effects of ponatinib on Ph-negative clone populations and secondary hematologic neoplasms need to be clarified.

\section{Competing interests}

The authors declare that they have no competing interests.

Authors' contributions

\begin{tabular}{|l|c|c|c|c|c|}
\hline Authors' contributions & WM & HJO & XW & BF & DS \\
\hline Research concept and design & $\checkmark$ & -- & -- & -- & $\checkmark$ \\
\hline Collection and/or assembly of data & $\checkmark$ & $\checkmark$ & $\checkmark$ & -- & -- \\
\hline Data analysis and interpretation & $\checkmark$ & $\checkmark$ & $\checkmark$ & $\checkmark$ & $\checkmark$ \\
\hline Writing the article & $\checkmark$ & -- & -- & -- & -- \\
\hline Critical revision of the article & $\checkmark$ & $\checkmark$ & -- & -- & $\checkmark$ \\
\hline Final approval of article & $\checkmark$ & $\checkmark$ & $\checkmark$ & $\checkmark$ & $\checkmark$ \\
\hline Statistical analysis & -- & -- & -- & -- & -- \\
\hline
\end{tabular}

Publication history

Editor: Sabrina Tosi, Brunel University, UK.

Received: 07-Feb-2018 Final Revised: 14-Mar-2018

Accepted: 16-Mar-2018 Published: 04-Apr-2018

\section{References}

1. Sawyers CL. Chronic myeloid leukemia. N Engl J Med. 1999; 340:133040. | Article | PubMed

2. Baccarani M, Deininger MW, Rosti G, Hochhaus A, Soverini S, Apperley JF, Cervantes F, Clark RE, Cortes JE and Guilhot F et al. European LeukemiaNet recommendations for the management of chronic myeloid leukemia: 2013. Blood. 2013; 122:872-84. | Article | PubMed Abstract | PubMed FullText

3. Gorre ME, Mohammed M, Ellwood K, Hsu N, Paquette R, Rao PN and Sawyers CL. Clinical resistance to STI- 571 cancer therapy caused by BCRABL gene mutation or amplification. Science. 2001; 293:876-80. | Article I PubMed

4. Apperley JF. Part I: mechanisms of resistance to imatinib in chronic myeloid leukaemia. Lancet Oncol. 2007; 8:1018-29. | Article | PubMed

5. O'Hare T, Shakespeare WC, Zhu X, Eide CA, Rivera VM, Wang F, Adrian LT, Zhou T, Huang WS, Xu Q, Metcalf CA, $3^{\text {rd }}$ and Tyner JW et al. AP24534, a pan-BCR-ABL inhibitor for chronic myeloid leukemia, potently inhibits the T315I mutant and overcomes mutation-based resistance. Cancer Cell. 2009; 16:401-12. | Article | PubMed Abstract | PubMed FullText

6. Cortes JE, Kim DW, Pinilla-Ibarz J, le Coutre P, Paquette R, Chuah C, Nicolini FE, Apperley JF, Khoury HJ, Talpaz M, DiPersio J, DeAngelo DJ, Abruzzese E, Rea D, Baccarani M and Muller MC et al. A phase 2 trial of ponatinib in Philadelphia chromosome-positive leukemias. $N$ Engl J Med. 2013; 369:1783-96. | Article | PubMed Abstract | PubMed FullText

7. Zabriskie MS, Eide CA, Tantravahi SK, Vellore NA, Estrada J, Nicolini FE, Khoury HJ, Larson RA, Konopleva M, Cortes JE, Kantarjian H, Jabbour EJ, Kornblau SM, Lipton JH, Rea D, Stenke L, Barbany G, Lange T, HernandezBoluda JC, Ossenkoppele GJ, Press RD and Chuah C et al. BCR-ABL1 compound mutations combining key kinase domain positions confer clinical resistance to ponatinib in $\mathrm{Ph}$ chromosome-positive leukemia. Cancer Cell. 2014; 26:428-442. | Article | PubMed Abstract | PubMed FullText

8. Lima L, Bernal-Mizrachi L, Saxe D, Mann KP, Tighiouart M, Arellano M, Heffner L, McLemore M, Langston A, Winton E and Khoury HJ. Peripheral blood monitoring of chronic myeloid leukemia during treatment with imatinib, second-line agents, and beyond. Cancer. 2011; 117:1245-52. | Article | PubMed

9. Press RD, Kamel-Reid S and Ang D. BCR-ABL1 RT-qPCR for monitoring the molecular response to tyrosine kinase inhibitors in chronic myeloid leukemia. J Mol Diagn. 2013; 15:565-76. | Article | PubMed

10. Soverini S, de Benedittis C, Mancini M and Martinelli G. Mutations in the BCR-ABL1 Kinase Domain and Elsewhere in Chronic Myeloid Leukemia. Clin Lymphoma Myeloma Leuk. 2015; 15 Suppl:S120-8. | Article | PubMed

11. Grossmann V, Kohlmann A, Zenger M, Schindela S, Eder C, Weissmann S, Schnittger S, Kern W, Muller MC, Hochhaus A, Haferlach T and Haferlach C. A deep-sequencing study of chronic myeloid leukemia patients in blast crisis (BC-CML) detects mutations in $\mathbf{7 6 . 9 \%}$ of cases. Leukemia. 2011; 25:557-60. | Article | PubMed

12. Cortes JE, Talpaz M, Giles F, O'Brien S, Rios MB, Shan J, Garcia-Manero G, Faderl S, Thomas DA, Wierda W, Ferrajoli A, Jeha S and Kantarjian HM. Prognostic significance of cytogenetic clonal evolution in patients with chronic myelogenous leukemia on imatinib mesylate therapy. Blood. 2003; 101:3794-800. | Article | PubMed

13. O'Dwyer ME, Mauro MJ, Kurilik G, Mori M, Balleisen S, Olson S, Magenis $E$, Capdeville R and Druker BJ. The impact of clonal evolution on response to imatinib mesylate (STI571) in accelerated phase CML. Blood. 2002; 100:1628-33. | Article | PubMed

14. Dierov J, Sanchez PV, Burke BA, Padilla-Nash H, Putt ME, Ried T and Carroll M. BCR/ABL induces chromosomal instability after genotoxic stress and alters the cell death threshold. Leukemia. 2009; 23:279-86. Article | PubMed Abstract | PubMed FullText

15. Cortes $\mathrm{J}$ and O'Dwyer ME. Clonal evolution in chronic myelogenous leukemia. Hematol Oncol Clin North Am. 2004; 18:671-84, x. | Article | PubMed

16. Koptyra M, Falinski R, Nowicki MO, Stoklosa T, Majsterek I, NieborowskaSkorska M, Blasiak J and Skorski T. BCR/ABL kinase induces selfmutagenesis via reactive oxygen species to encode imatinib resistance. Blood. 2006; 108:319-27. | Article | PubMed Abstract | PubMed FullText

17. Fayad L, Kantarjian $H, O$ 'Brien S, Seong D, Albitar M, Keating $M$ and Talpaz M. Emergence of new clonal abnormalities following interferonalpha induced complete cytogenetic response in patients with chronic myeloid leukemia: report of three cases. Leukemia. 1997; 11:767-71. | PubMed

18. Medina J, Kantarjian H, Talpaz M, O’Brien S, Garcia-Manero G, Giles $\mathrm{F}$, Rios MB, Hayes K and Cortes J. Chromosomal abnormalities in Philadelphia chromosome-negative metaphases appearing during imatinib mesylate therapy in patients with Philadelphia chromosomepositive chronic myelogenous leukemia in chronic phase. Cancer. 2003; 98:1905-11. | Article | PubMed 
McCarvill et al. Hematology and Leukemia 2018,

19. Groves MJ, Sales M, Baker L, Griffiths M, Pratt N and Tauro S. Factors influencing a second myeloid malignancy in patients with Philadelphianegative $\mathbf{- 7}$ or $\operatorname{del}(\mathbf{7 q})$ clones during tyrosine kinase inhibitor therapy for chronic myeloid leukemia. Cancer Genet. 2011; 204:39-44. | Article I PubMed

20. Zeidan A, Kakati S, Anderson B, Barcos M and Wetzler M. Monosomy 7 in $\mathrm{t}(9 ; 22)$-negative cells during nilotinib therapy in an imatinib-resistant chronic myeloid leukemia case. Cancer Genet Cytogenet. 2007; 176:16971. | Article | PubMed Abstract | PubMed FullText

21. Navarro JT, Feliu E, Grau J, Espinet B, Colomer D, Ribera JM, Oriol A, Granada I, Junca J and Milla F. Monosomy 7 with severe myelodysplasia developing during imatinib treatment of Philadelphia-positive chronic myeloid leukemia: two cases with a different outcome. Am J Hematol. 2007; 82:849-51. | Article | PubMed

22. Kovitz C, Kantarjian H, Garcia-Manero G, Abruzzo LV and Cortes J. Myelodysplastic syndromes and acute leukemia developing after imatinib mesylate therapy for chronic myeloid leukemia. Blood. 2006; 108:2811-3. | Article | PubMed

23. Deininger MW, Cortes J, Paquette R, Park B, Hochhaus A, Baccarani M, Stone R, Fischer T, Kantarjian H, Niederwieser D, Gambacorti-Passerini C, So C, Gathmann I, Goldman JM, Smith D, Druker BJ and Guilhot F. The prognosis for patients with chronic myeloid leukemia who have clonal cytogenetic abnormalities in philadelphia chromosome-negative cells. Cancer. 2007; 110:1509-19. | Article | PubMed

24. Hofmann WK and Koeffler HP. Myelodysplastic syndrome. Annu Rev Med. 2005; 56:1-16. | Article | PubMed

25. Greenberg PL, Tuechler H, Schanz J, Sanz G, Garcia-Manero G, Sole F, Bennett JM, Bowen D, Fenaux P and Dreyfus F et al. Revised international prognostic scoring system for myelodysplastic syndromes. Blood. 2012; 120:2454-65. | Article | PubMed Abstract | PubMed FullText

26. Malcovati L, Hellstrom-Lindberg E, Bowen D, Ades L, Cermak J, Del Canizo C, Della Porta MG, Fenaux P, Gattermann N, Germing U, Jansen JH, Mittelman M, Mufti G, Platzbecker U, Sanz GF, Selleslag D, Skov-Holm M, Stauder R, Symeonidis A, van de Loosdrecht AA, de Witte T and Cazzola $M$. Diagnosis and treatment of primary myelodysplastic syndromes in adults: recommendations from the European LeukemiaNet. Blood. 2013; 122:2943-64. | Article | PubMed Abstract | PubMed FullText

27. Soverini S, Colarossi S, Gnani A, Castagnetti F, Rosti G, Bosi C, Paolini S, Rondoni M, Piccaluga PP, Palandri F, Giannoulia P, Marzocchi G, Luatti S, Testoni N, lacobucci I, Cilloni D, Saglio G, Baccarani M and Martinelli G. Resistance to dasatinib in Philadelphia-positive leukemia patients and the presence or the selection of mutations at residues 315 and 317 in the BCR-ABL kinase domain. Haematologica. 2007; 92:401-4. | Article | PubMed

28. Bower H, Bjorkholm M, Dickman PW, Hoglund M, Lambert PC and Andersson TM. Life Expectancy of Patients With Chronic Myeloid Leukemia Approaches the Life Expectancy of the General Population. $J$ Clin Oncol. 2016; 34:2851-7. | Article | PubMed

29. Cortes J, Quintas-Cardama A and Kantarjian HM. Monitoring molecular response in chronic myeloid leukemia. Cancer. 2011; 117:1113-22. | Article | PubMed Abstract | PubMed FullText

30. O'Hare T, Eide CA and Deininger MW. Bcr-Abl kinase domain mutations, drug resistance, and the road to a cure for chronic myeloid leukemia. Blood. 2007; 110:2242-9. | Article | PubMed

31. Haznedaroglu IC. Drug Therapy in the Progressed CML Patient with multi-TKI Failure. Mediterr J Hematol Infect Dis. 2015; 7:e2015014. | Article | PubMed Abstract | PubMed FullText

32. Soverini S, Hochhaus A, Nicolini FE, Gruber F, Lange T, Saglio G, Pane F, Muller MC, Ernst T, Rosti G, Porkka K, Baccarani M, Cross NC and Martinelli G. BCR-ABL kinase domain mutation analysis in chronic myeloid leukemia patients treated with tyrosine kinase inhibitors: recommendations from an expert panel on behalf of European LeukemiaNet. Blood. 2011; 118:1208-15. | Article | PubMed

33. O'Hare T, Walters DK, Stoffregen EP, Jia T, Manley PW, Mestan J, CowanJacob SW, Lee FY, Heinrich MC, Deininger MW and Druker BJ. In vitro activity of Bcr-Abl inhibitors AMN107 and BMS-354825 against clinically relevant imatinib-resistant Abl kinase domain mutants. Cancer Res. 2005; 65:4500-5. | Article | PubMed

34. Padron E, Komrokji R and List AF. The 5q- syndrome: biology and treatment. Curr Treat Options Oncol. 2011; 12:354-68. | Article | PubMed

35. Sun J, Yin CC, Cui W, Chen SS, Medeiros LJ and Lu G. Chromosome 20q deletion: a recurrent cytogenetic abnormality in patients with chronic myelogenous leukemia in remission. Am J Clin Pathol. 2011; 135:391-7. | Article | PubMed

36. Huh J, Tiu RV, Gondek LP, O’Keefe CL, Jasek M, Makishima H, Jankowska AM, Jiang Y, Verma A, Theil KS, McDevitt MA and Maciejewski JP. Characterization of chromosome arm 20q abnormalities in myeloid malignancies using genome-wide single nucleotide polymorphism array analysis. Genes Chromosomes Cancer. 2010; 49:390-9. | Article | PubMed

37. Bumm T, Muller C, Al-Ali HK, Krohn K, Shepherd P, Schmidt E, Leiblein S, Franke C, Hennig E, Friedrich T, Krahl R, Niederwieser D and Deininger $\mathrm{MW}$. Emergence of clonal cytogenetic abnormalities in Ph- cells in some CML patients in cytogenetic remission to imatinib but restoration of polyclonal hematopoiesis in the majority. Blood. 2003; 101:1941-9. Article I PubMed

38. O'Dwyer ME, Gatter KM, Loriaux M, Druker BJ, Olson SB, Magenis RE, Lawce H, Mauro MJ, Maziarz RT and Braziel RM. Demonstration of Philadelphia chromosome negative abnormal clones in patients with chronic myelogenous leukemia during major cytogenetic responses induced by imatinib mesylate. Leukemia. 2003; 17:481-7. | Article | PubMed

39. Jawad MD, Go RS, Ketterling RP, Begna KH, Reichard KK and Shi M. Transient monosomy 7 in a chronic myelogenous leukemia patient during nilotinib therapy: a case report. Clin Case Rep. 2016; 4:282-6. | Article | PubMed Abstract | PubMed FullText

40. Lang F, Wunderle L, Pfeifer H, Schnittger S, Bug G and Ottmann OG. Dasatinib and Azacitidine Followed by Haploidentical Stem Cell Transplant for Chronic Myeloid Leukemia with Evolving Myelodysplasia: A Case Report and Review of Treatment Options. Am J Case Rep. 2017; 18:1099-1109. | Article | PubMed Abstract | PubMed FullText

41. Schmidt M, Rinke J, Schafer V, Schnittger S, Kohlmann A, Obstfelder E, Kunert C, Ziermann J, Winkelmann N, Eigendorff E, Haferlach T, Haferlach $C$, Hochhaus A and Ernst T. Molecular-defined clonal evolution in patients with chronic myeloid leukemia independent of the BCR-ABL status. Leukemia. 2014; 28:2292-9. | Article | PubMed

42. Bejar R, Stevenson K, Abdel-Wahab O, Galili N, Nilsson B, Garcia-Manero G, Kantarjian H, Raza A, Levine RL, Neuberg D and Ebert BL. Clinical effect of point mutations in myelodysplastic syndromes. N Engl J Med. 2011; 364:2496-506. | Article | PubMed Abstract | PubMed FullText

43. Gozgit JM, Wong MJ, Wardwell S, Tyner JW, Loriaux MM, Mohemmad QK, Narasimhan NI, Shakespeare WC, Wang F, Druker BJ, Clackson T and Rivera VM. Potent activity of ponatinib (AP24534) in models of FLT3driven acute myeloid leukemia and other hematologic malignancies. Mol Cancer Ther. 2011; 10:1028-35. | Article | PubMed Abstract | PubMed FullText

\section{Citation:}

McCarvill W, Olney HJ, Weng X, Fan B and Soulières D. Case report: Efficacy of ponatinib in a case of chronic myeloid leukemia with a complicated clonal evolution including a myelodysplastic syndrome. Hematol Leuk. 2018; 6:3.

http://dx.doi.org/10.7243/2052-434X-6-3 